\title{
Biofuel and Bioenergy Technology
}

\author{
Wei-Hsin Chen ${ }^{1, * \mathbb{C}}$, Keat Teong Lee ${ }^{2, *}$ and Hwai Chyuan Ong ${ }^{3, *}$ \\ 1 Department of Aeronautics and Astronautics, National Cheng Kung University, Tainan 701, Taiwan \\ 2 School of Chemical Engineering, Universiti Sains Malaysia, Nibong Tebal 14300, Pulau Pinang, Malaysia \\ 3 Department of Mechanical Engineering, University of Malaya, Kuala Lumpur 50603, Malaysia \\ * Correspondence: chenwh@mail.ncku.edu.tw or weihsinchen@gmail.com (W.-H.C.); ktlee@usm.my (K.T.L.); \\ onghc@um.edu.my (H.C.O.)
}

Received: 24 December 2018; Accepted: 10 January 2019; Published: 18 January 2019

\section{Introduction}

Biomass is considered as a renewable resource because of its short life cycle, and biomass-derived biofuels are potential substitutes to fossil fuels. When biomass grows, all carbon in biomass comes from the atmosphere and is liberated into the environment when it is burned. Therefore, biomass is thought of as a carbon-neutral fuel. For these reasons, the development of bioenergy is an effective countermeasure to elongate fossil fuel reserves, lessen greenhouse gas (GHG) emissions, and mitigate global warming and climate change. Biomass can be converted into biofuels through a variety of routes such as physical, thermochemical, chemical, and biological methods. The common and important biofuels for bioenergy include charcoal, biochar, biodiesel, bioethanol, biobutanol, pyrolysis and liquefaction bio-oils, synthesis gas (syngas), biogas, and biohydrogen, etc. On account of the merit of bioenergy for environmental sustainability, biofuel and bioenergy technology plays a crucial role for renewable energy development. This Special Issue aims to publish high-quality review and research papers, addressing recent advances in biofuel and bioenergy. State-of-the-art studies of advanced techniques of biorefinery for biofuel production are also included. Research involving experimental studies, recent developments, and novel and emerging technologies in this field are covered. The particular topics of interest in the original call for papers included, but were not limited to:

- Novel and unexploited biomass resources for biofuel and bioenergy production

- New emerging technologies for biofuel and bioenergy production

- Development of thermochemical conversion routes for biofuel and bioenergy produciton

- Advanced biorefinery processes for biofuel and biochemicals production

- Bioreactors or microbial fuel cell for bioenergy and power production

- State-of-the-art review in the progress of biofuel and bioenergy technology

This Special Issue of Energies on the subject of "Biofuel and Bioenergy Technology" contains the successful invited submissions [1-27]. A total of twenty-seven technical papers which cover diversified biofuel and bioenergy technology related researches have shown critical results and contributed significant findings in biomass processing [1,2], bio-oil and biodiesel [3-11], syngas [12-14], biogas/methane [15-19], bioethanol and alcohol-based fuels [20-22], solid fuel [23-25] and also microbial fuel cell $[13,26,27]$ developments.

\section{Statistics of the Special Issue}

The response to our call had the following statistics:

- Submissions (46);

- Publications (27); 
- Rejections (19);

- Article types: research articles (25); review articles (2).

The authors' geographical distribution (published papers) is:

- Taiwan (8);

- Korea (4);

- Czech Republic (3)

- Australia (3);

- USA (2);

- China (1);

- Malaysia (1);

- Mexico (1);

- Pakistan (1);

- Poland (1);

- $\quad$ Spain (1);

- The Netherlands (1).

Published submissions are related to the most important techniques and analysis applied to the biofuel and bioenergy technology. In summary, the edition and selections of papers for this special issue are very inspiring and rewarding. We thank the editorial staff and reviewers for their efforts and help during the process.

\section{Brief Overview of the Contributions to This Special Issue}

Table 1 provides some of the key information, including the research type, field of study, final product as well as the key findings. As observed, a majority of the publications (twenty-three papers) focus on experimental work to improve or explore novel technologies for energy-products synthesis, while three papers focus on modelling studies and two papers focus on literature review studies. The following discussion highlights and groups the research findings in accordance to the corresponding research field or work.

As the initial step in most synthesis routes, biomass processing can enhance the substrate's quality for other synthesis processes. Thus, commonly, these are treated as pretreatment to enhance the characteristics of the biomass. In two research works [1,2], the combination of physical treatment (ball milling) and chemical treatment (ethanol organosolv) showed improved glucan digestibility. Three different biomasses such as giant miscanthus, corn stover and wheat straw were pretreated with ball milling and ethanol organosolv and the overall biomass size was reduced as a result of the prolonged pre-treatment [1]. Due to the improved physicochemical characteristics resulting from the pre-treatment, a maximum of $91 \%$ glucan digestibility could be achieved. A parametric study on combined ball milling and organosolv was performed as well to optimize the glucan digestibility [2]. It was determined that at $170{ }^{\circ} \mathrm{C}$, with reaction time of $90 \mathrm{~min}$ and ethanol concentration of $40 \%$ and liquid/solid ratio of 10, the pretreatment process achieved the best results. Thus, the biomass processing method could be beneficial in generating desired products. 
Table 1. Key Information of the Publications Submitted to Special Issue.

\begin{tabular}{|c|c|c|c|c|c|c|}
\hline \multirow{2}{*}{ Research Work } & \multicolumn{3}{|c|}{ Research Type } & \multirow{2}{*}{$\begin{array}{l}\text { Technology/ } \\
\text { Field of Work }\end{array}$} & \multirow{2}{*}{ Product } & \multirow{2}{*}{ Key Findings } \\
\hline & Experimental & Modelling & Review & & & \\
\hline $\begin{array}{l}\text { Anwar et al., } \\
2018 \text { [5] }\end{array}$ & $\mathrm{x}$ & & & Blending & $\begin{array}{l}\text { Biodiesel blend } \\
\text { of papaya seed } \\
\text { oil }\end{array}$ & $\begin{array}{l}\text { - } \quad \text { Reduction in brake power, torque and brake } \\
\text { thermal efficiency. } \\
\text { - } \quad \text { Significant effect on brake specific fuel consumption. }\end{array}$ \\
\hline $\begin{array}{l}\text { Anwar et al., } \\
2018 \text { [6] }\end{array}$ & $\mathrm{x}$ & & & $\begin{array}{l}\text { Alkali-catalysed } \\
\text { transesterification }\end{array}$ & $\begin{array}{l}\text { Australian } \\
\text { native stone } \\
\text { fruit biodiesel }\end{array}$ & $\begin{array}{l}\text { - } \quad \text { Optimisation with response surface methodology. } \\
\text { - } \quad \text { Maximum biodiesel yield of } 95.8 \% \text {. } \\
\text { - } \quad \text { Potential second-generation biodiesel. }\end{array}$ \\
\hline $\begin{array}{l}\text { Bidabadi et al., } \\
2018 \text { [25] }\end{array}$ & & $\mathrm{x}$ & & $\begin{array}{l}\text { Mathematic } \\
\text { asymptotic } \\
\text { technique }\end{array}$ & - & $\begin{array}{l}\text { - } \quad \text { Oxidizer and fuel Lewis number were between } 0.4 \\
\text { and } 1 \text {, the maximum flame temperature was } ~ 1860 \mathrm{~K} \text {. } \\
\text { Per unit of fuel Lewis number, the minimum } \\
\text { thermophoretic force was }-1.48 \times 10^{-8} \mathrm{~N} \text {. } \\
\text { - } \quad \text { Per unit of oxidizer Lewis number, the minimum } \\
\text { thermophoretic force was }-1.53 \times 10^{-8} \mathrm{~N} \text {. } \\
\text { - Per unit of porosity factor, the minimum } \\
\text { thermophoretic force was }-1.28 \times 10^{-8} \mathrm{~N} \text {. }\end{array}$ \\
\hline $\begin{array}{c}\text { Brunerová et al., } \\
2018 \text { [24] }\end{array}$ & $\mathrm{x}$ & & & $\begin{array}{l}\text { High-Pressure } \\
\text { Densification }\end{array}$ & $\begin{array}{l}\text { Bio-Briquette } \\
\text { Fuel }\end{array}$ & $\begin{array}{l}\text { - Low ash content for bamboo fibre }(1.16 \%) \text { and } \\
\text { sugarcane skin }(8.62 \%) \text {. } \\
\text { - Satisfactory mechanical durability for bamboo fibre } \\
(97.80 \%) \text { and sugarcane skin }(97.70 \%) \text {. } \\
\text { - These products can be used for bio-briquette } \\
\text { fuel production. }\end{array}$ \\
\hline
\end{tabular}


Table 1. Cont.

\begin{tabular}{|c|c|c|c|c|c|c|}
\hline \multirow{2}{*}{ Research Work } & \multicolumn{3}{|c|}{ Research Type } & \multirow{2}{*}{$\begin{array}{l}\text { Technology/ } \\
\text { Field of Work }\end{array}$} & \multirow{2}{*}{ Product } & \multirow{2}{*}{ Key Findings } \\
\hline & Experimental & Modelling & Review & & & \\
\hline $\begin{array}{l}\text { Černý et al., } \\
2018 \text { [15] }\end{array}$ & $\mathrm{x}$ & & & $\begin{array}{l}\text { Biogas study with } \\
\text { DNA analysis }\end{array}$ & $\begin{array}{c}\text { Biogas } \\
\text { (Hydrogen) }\end{array}$ & $\begin{array}{l}\text { - Occurrence of potentially harmful microorganisms } \\
\text { such as Clostridium novyi was detected at higher ratio } \\
(65.63 \%) \text { in the population of the bioreactor. }\end{array}$ \\
\hline $\begin{array}{l}\text { Chein et al., } \\
2018 \text { [12] }\end{array}$ & $x$ & & & $\begin{array}{l}\text { Tri-Reforming } \\
\text { Process }\end{array}$ & $\begin{array}{c}\text { Syngas } \\
\text { (hydrogen) }\end{array}$ & $\begin{array}{l}\text { - First-Law Efficiency increased with increased reaction } \\
\text { temperature for higher hydrogen and carbon } \\
\text { monoxide yields. } \\
\text { - Second-Law Efficiency decreased with increased } \\
\text { reaction temperature due to more complete } \\
\text { chemical reaction. }\end{array}$ \\
\hline $\begin{array}{l}\text { Chen et al., } \\
2018 \text { [3] }\end{array}$ & $\mathrm{x}$ & & & Pyrolysis & Pyrolytic Oil & $\begin{array}{l}\text { - Optimisation with Taguchi Method. } \\
\text { - } \quad \text { Maximum pyrolytic oil yield of } 10.19 \% \text {. } \\
\text { - Synthesis conditions: } 450{ }^{\circ} \mathrm{C}, 60 \mathrm{~min}, 10^{\circ} \mathrm{C} / \mathrm{min} \text { and } \\
\text { nitrogen flow of } 700 \mathrm{~mL} / \mathrm{min} \text {. }\end{array}$ \\
\hline $\begin{array}{l}\text { Chen et al., } \\
2018 \text { [26] }\end{array}$ & $\mathrm{x}$ & & & $\begin{array}{l}\text { Microbial } \\
\text { Fuel Cell }\end{array}$ & - & $\begin{array}{l}\text { - Hydrodynamic boundary layer of } 1.6 \mathrm{~cm} \text { (thin layer) } \\
\text { showed maximum voltage of } 22 \mathrm{mV} \text { and charged } \\
\text { transfer resistance of } 39 \Omega \text {. }\end{array}$ \\
\hline $\begin{array}{l}\text { David et al., } \\
2018 \text { [18] }\end{array}$ & $x$ & & & $\begin{array}{l}\text { Thermophilic } \\
\text { anaerobic } \\
\text { digestion }\end{array}$ & Methane & $\begin{array}{l}\text { Food wastes (corn stover, prairie cordgrass and } \\
\text { unbleached paper) undergone thermophilic } \\
\text { anaerobic digestion. } \\
\text { Highest methane yield of } 305.45 \mathrm{~L} / \mathrm{kg} \text { was achieved } \\
\text { after } 30 \text { days of incubation at } 60^{\circ} \mathrm{C} \text { at } 100 \mathrm{rpm} \text {. }\end{array}$ \\
\hline
\end{tabular}


Table 1. Cont.

\begin{tabular}{|c|c|c|c|c|c|c|}
\hline \multirow{2}{*}{ Research Work } & \multicolumn{3}{|c|}{ Research Type } & \multirow{2}{*}{$\begin{array}{l}\text { Technology/ } \\
\text { Field of Work }\end{array}$} & \multirow{2}{*}{ Product } & \multirow{2}{*}{ Key Findings } \\
\hline & Experimental & Modelling & Review & & & \\
\hline $\begin{array}{l}\text { Dziekońska- } \\
\text { Kubczak et al., } \\
2018 \text { [20] }\end{array}$ & $\mathrm{x}$ & & & $\begin{array}{l}\text { Nitric acid } \\
\text { pretreatment for } \\
\text { enzymatic } \\
\text { hydrolysis and } \\
\text { fermentation }\end{array}$ & Bioethanol & $\begin{array}{l}\text { - Jerusalem artichoke stalks were converted into } \\
\text { bioethanol with nitric acid as catalyst. } \\
\text { Nitric acid pretreated hydrolysates led to } 30 \% \\
\text { improvement in ethanol yield (77-82\% of } \\
\text { theoretical yield). }\end{array}$ \\
\hline $\begin{array}{l}\text { Encinar et al., } \\
2018 \text { [7] }\end{array}$ & $\mathrm{x}$ & & & $\begin{array}{l}\text { Transesterification } \\
\text { with base- } \\
\text { catalysed } \\
\text { reactions }\end{array}$ & Biodiesel & $\begin{array}{l}\text { - Ultrasonic accelerated rate of biodiesel } \\
\text { transesterification reactions. } \\
\text { - } \quad \text { Reaction followed a pseudo-first order kinetic model. }\end{array}$ \\
\hline $\begin{array}{l}\text { Eri et al., } \\
2018 \text { [14] }\end{array}$ & & $\mathrm{x}$ & & $\begin{array}{l}\text { Equilibrium } \\
\text { constants } \\
\text { modelling }\end{array}$ & - & $\begin{array}{l}\text { - Simulations were performed with two different } \\
\text { models (with and without tar). } \\
\text { - The simulations were validated by experimental data. }\end{array}$ \\
\hline $\begin{array}{l}\text { Fernedas et al., } \\
\quad 2018 \text { [13] }\end{array}$ & $\mathrm{x}$ & $\mathrm{x}$ & & $\begin{array}{l}\text { Gasifier-Specific } \\
\text { Solid Oxide Fuel } \\
\text { Cell System }\end{array}$ & - & $\begin{array}{l}\text { - Validation data showed good agreement between } \\
\text { experimental and simulation data. } \\
\text { - System efficiencies were estimated to be } 33.7-34.5 \% \text {. }\end{array}$ \\
\hline $\begin{array}{l}\text { Kim et al., } \\
2018 \text { [10] }\end{array}$ & $\mathrm{x}$ & & & $\begin{array}{l}\text { Photobioreactor } \\
\text { with coal-fired } \\
\text { flue-gas }\end{array}$ & $\begin{array}{c}\text { Microalgal } \\
\text { biodiesel }\end{array}$ & $\begin{array}{l}\text { - M082 strain showed maximum lipid content (397 mg } \\
\text { fatty acid methyl ester (FAME)/g cell) with good } \\
\text { tolerance to high temperature. } \\
\text { - } \quad \text { FAME produced met the international standards. }\end{array}$ \\
\hline
\end{tabular}


Table 1. Cont

\begin{tabular}{|c|c|c|c|c|c|c|}
\hline \multirow{2}{*}{ Research Work } & \multicolumn{3}{|c|}{ Research Type } & \multirow{2}{*}{$\begin{array}{l}\text { Technology/ } \\
\text { Field of Work }\end{array}$} & \multirow{2}{*}{ Product } & \multirow{2}{*}{ Key Findings } \\
\hline & Experimental & Modelling & Review & & & \\
\hline $\begin{array}{l}\text { Kim et al., } \\
2018 \text { [1] }\end{array}$ & $\mathrm{x}$ & & & $\begin{array}{c}\text { Ball milling and } \\
\text { ethanol } \\
\text { organosolv }\end{array}$ & - & $\begin{array}{l}\text { - Combined pretreatment on giant miscanthus, } \\
\text { corn stover and wheat straw show varied results } \\
\text { (increased of glucan content for giant miscanthus, } \\
\text { removal of cellulose for corn stover). } \\
\text { Enzymatic digestibility was improved with } 91 \% \\
\text { glucan digestibility. }\end{array}$ \\
\hline $\begin{array}{c}\text { Kim et al., } \\
2018 \text { [2] }\end{array}$ & $\mathrm{x}$ & & & $\begin{array}{c}\text { Ball milling and } \\
\text { ethanol } \\
\text { organosolv }\end{array}$ & - & $\begin{array}{l}\text { - Pretreatment was performed using a } 30 \mathrm{~L} \text { bench-scale } \\
\text { ball mill reactor. } \\
\text { Pretreatment conditions were varied: room } \\
\text { temperature to } 170{ }^{\circ} \mathrm{C} \text {, time from } 30 \text { to } 120 \mathrm{~min} \text {, } \\
\text { ethanol concentration from } 30 \% \text { to } 60 \% \text {, liquid /solid } \\
\text { ratio from } 10 \text { to } 20 . \\
\text { - Highest glucan digestibility was performed at } 170{ }^{\circ} \mathrm{C} \text {, } \\
\text { reaction time to } 90 \mathrm{~min}, 40 \% \text { of ethanol concentration } \\
\text { and } \mathrm{L} / \mathrm{S}=10 \text {. }\end{array}$ \\
\hline $\begin{array}{l}\text { Kuan et al., } \\
2018 \text { [8] }\end{array}$ & $\mathrm{x}$ & & & Transesterification & Biodiesel & $\begin{array}{l}\text { - } \quad \text { Acid-catalysed synthesis by } 0.6 \mathrm{M} \text { sulphuric acid at } \\
70{ }^{\circ} \mathrm{C} \text { for } 20 \mathrm{~h} \text { yielded } 111 \% \text { of FAME. } \\
\text { Base-catalysed synthesis by } 1.0 \mathrm{~g} / \mathrm{L} \text { of sodium } \\
\text { hydroxide at } 70{ }^{\circ} \mathrm{C} \text { for } 10 \mathrm{~h} \text { yielded } 102 \% \text { of FAME. } \\
\text { - } \quad \text { Direct transesterification shortened the reaction time } \\
\text { and improved FAME yield. }\end{array}$ \\
\hline
\end{tabular}


Table 1. Cont.

\begin{tabular}{|c|c|c|c|c|c|c|}
\hline \multirow{2}{*}{ Research Work } & \multicolumn{3}{|c|}{ Research Type } & \multirow{2}{*}{$\begin{array}{l}\text { Technology/ } \\
\text { Field of Work }\end{array}$} & \multirow{2}{*}{ Product } & \multirow{2}{*}{ Key Findings } \\
\hline & Experimental & Modelling & Review & & & \\
\hline $\begin{array}{l}\text { Längauer et al., } \\
2018 \text { [4] }\end{array}$ & $\mathrm{x}$ & & & $\begin{array}{l}\text { Simultaneous } \\
\text { Extraction and } \\
\text { Emulsification }\end{array}$ & $\begin{array}{l}\text { Emulsified } \\
\text { bio-oil }\end{array}$ & 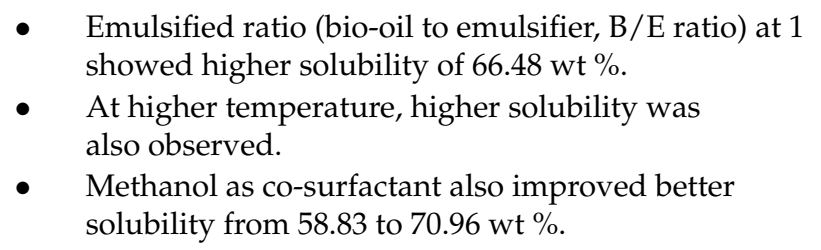 \\
\hline $\begin{array}{l}\text { Li et al., } \\
2018 \text { [21] }\end{array}$ & $\mathrm{x}$ & & & $\begin{array}{l}\text { Electrochemical } \\
\text { Hydrogenation } \\
\text { using polymer } \\
\text { electrolyte } \\
\text { membrane reactor }\end{array}$ & Isopropanol & $\begin{array}{l}\text { - Polymer electrolyte membrane fuel cell was used to } \\
\text { produce isopropanol as main product and } \\
\text { diisopropyl ether as byproduct. } \\
\text { - High selectivity and }(>90 \%) \text { and high current } \\
\text { efficiency }(59.7 \%) \text { were observed at mild conditions of } \\
65^{\circ} \mathrm{C} \text { and at atmospheric pressure. }\end{array}$ \\
\hline $\begin{array}{l}\text { Musa et al., } \\
2018 \text { [19] }\end{array}$ & & & $\mathrm{x}$ & $\begin{array}{l}\text { Anaerobic } \\
\text { Membrane } \\
\text { Bioreactors } \\
\text { (AnMBRs) }\end{array}$ & - & $\begin{array}{l}\text { Anaerobic digestion technologies were } \\
\text { critically reviewed. } \\
\text { Factors on membrane fouling, microbial environment } \\
\text { conditions as well as parameters on the operations of } \\
\text { AnMBRs were discussed. } \\
\text { - Microfiltration as the mean to reduce energy and } \\
\text { water usage in the AnMBRs was suggested. }\end{array}$ \\
\hline $\begin{array}{c}\text { Nguyen et al., } \\
2018 \text { [11] }\end{array}$ & $\mathrm{x}$ & & & $\begin{array}{l}\text { Liquid Lipase } \\
\text { Catalyzed } \\
\text { Esterification }\end{array}$ & Biodiesel & $\begin{array}{l}\text { - } \quad \text { Optimisation with Response Surface Methodology } \\
\text { - } \quad \text { Superadsorbent polymer (SAP), as water removal } \\
\text { agent, was used in esterification. } \\
\text { - } \quad \text { The polymer improved the conversion to } 96.73 \% \text { at } \\
35.25{ }^{\circ} \mathrm{C} \text {, methanol to oleic acid molar ratio of } 3.44: 1 \text {, } \\
\text { SAP loading of } 10.55 \% \text { and enzyme loading of } 11.98 \% \text {. }\end{array}$ \\
\hline
\end{tabular}


Table 1. Cont

\begin{tabular}{|c|c|c|c|c|c|c|}
\hline \multirow{2}{*}{ Research Work } & \multicolumn{3}{|c|}{ Research Type } & \multirow{2}{*}{$\begin{array}{l}\text { Technology/ } \\
\text { Field of Work }\end{array}$} & \multirow{2}{*}{ Product } & \multirow{2}{*}{ Key Findings } \\
\hline & Experimental & Modelling & Review & & & \\
\hline $\begin{array}{l}\text { Poudel et al., } \\
2018 \text { [23] }\end{array}$ & $\mathrm{x}$ & & & Torrefaction & $\begin{array}{l}\text { Torrefied } \\
\text { Biomass }\end{array}$ & $\begin{array}{l}\text { - Wood waste was torrefied at } 200-400{ }^{\circ} \mathrm{C} \text { and } \\
0-50 \mathrm{~min} \text {. } \\
\text { - } \quad 300{ }^{\circ} \mathrm{C} \text { as the optimal temperature for torrefaction } \\
\text { based on Van Krevelen diagram. }\end{array}$ \\
\hline $\begin{array}{l}\text { Rahman et al., } \\
2018 \text { [22] }\end{array}$ & & & $\mathrm{x}$ & $\begin{array}{l}\text { Bio-hydrocarbon } \\
\text { Production in } \\
\text { Bacteria }\end{array}$ & - & $\begin{array}{l}\text { - } \quad \text { Bioenergy products (alcohols and } n \text {-alkene } \\
\text { hydrocarbons }\left(C_{2} \text { to } C_{18}\right) \text { as produced by engineered } \\
\text { microorganisms showed promising energy potential. } \\
\text { The review discussed the complexity of metabolic } \\
\text { networks to obtain these bio-hydrocarbon products. }\end{array}$ \\
\hline $\begin{array}{l}\text { Roubík, et al., } \\
2018 \text { [16] }\end{array}$ & $\mathrm{x}$ & & & $\begin{array}{l}\text { Biogas Plant } \\
\text { Study }\end{array}$ & $\begin{array}{c}\text { Biogas } \\
\text { (methane) }\end{array}$ & $\begin{array}{l}\text { - } \quad \text { Biogas composition was measured for } 107 \text { small-scale } \\
\text { biogas plants, respectively. } \\
\text { Mean compositions as follows: For plants younger } \\
\text { than } 5 \text { years, } \mathrm{CH}_{4} \text { was } 65.44 \% \text { and } \mathrm{CO}_{2} \text { was } 29.31 \% \text {; } \\
\text { for plants older than } 5 \text { years, } \mathrm{CH}_{4} \text { was } 64.57 \% \text { and } \\
\mathrm{CO}_{2} \text { was } 29.93 \% \text {. }\end{array}$ \\
\hline Su et al., 2018 [9] & $\mathrm{x}$ & & & $\begin{array}{l}\text { Two-step } \\
\text { acid-catalysed } \\
\text { transesterification }\end{array}$ & Biodiesel & $\begin{array}{l}\text { - } \quad \text { Soursop (Annona muricata) seeds were used to } \\
\text { produce bio-oil }(29.6 \%(w / w)) \text {. } \\
\text { Bio-diesel with highest of } 97.02 \% \text { was produced } \\
\text { under acid-catalysed conditions of } 65{ }^{\circ} \mathrm{C}, 1 \% \\
\text { sulphuric acid, reaction time of } 90 \text { min and methanol: } \\
\text { oil ratio of } 10: 1 \text { and under base-catalysed conditions } \\
\text { of } 65{ }^{\circ} \mathrm{C}, 0.6 \% \mathrm{NaOH} \text {, reaction time of } 30 \text { min and } \\
\text { methanol: oil ratio of } 8: 1 \text {. } \\
\text { Produced biodiesel met the EN14214 and } \\
\text { D6751 requirements. }\end{array}$ \\
\hline
\end{tabular}


Table 1. Cont.

\begin{tabular}{|c|c|c|c|c|c|c|}
\hline \multirow{2}{*}{ Research Work } & \multicolumn{3}{|c|}{ Research Type } & \multirow{2}{*}{$\begin{array}{c}\text { Technology/ } \\
\text { Field of Work }\end{array}$} & \multirow{2}{*}{ Product } & \multirow{2}{*}{ Key Findings } \\
\hline & Experimental & Modelling & Review & & & \\
\hline $\begin{array}{c}\text { Valero et al., } \\
2018 \text { [17] }\end{array}$ & $\mathrm{x}$ & & & - & Biomethane & $\begin{array}{l}\text { - Biochemical Methane Potential (BMP) showed that } \\
\text { the addition of granular activated carbon (GAC) } \\
\text { improved the methane yield by } 34 \% \text { for instance } \\
\text { testing and } 54 \% \text { for } 10 \text { days of GAC } \\
\text { biofilm development. } \\
\text { - Addition of GAC can improve digester's anaerobic } \\
\text { digestion performance. }\end{array}$ \\
\hline $\begin{array}{l}\text { Wu et al., } \\
2018 \text { [27] }\end{array}$ & $\mathrm{x}$ & & & $\begin{array}{c}\text { Microbial Fuel } \\
\text { Cell }\end{array}$ & - & $\begin{array}{l}\text { - Different calcination temperatures }\left(500-900{ }^{\circ} \mathrm{C}\right) \text { of } \\
\text { iron oxide }\left(\mathrm{F}_{\mathrm{e} 2} \mathrm{O}_{3}\right) \text { were tested to investigate their } \\
\text { photocatalytic properties within the } \\
\text { cathodic chambers. } \\
\text { - Calcinated } \mathrm{F}_{\mathrm{e} 2} \mathrm{O}_{3} \text { improved the bio-electro-Fenton } \\
\text { microbial fuel cell (Bio-E-Fenton-MFC) on degrading } \\
\text { oily wastewater. } \\
\text { Within one hour, oily water was best-degraded up to } \\
99.3 \% \text { with electrode material synthesised at } 500{ }^{\circ} \mathrm{C} \\
\text { with maximum power density of } 52.5 \mathrm{~mW} / \mathrm{m}^{2} \text {. }\end{array}$ \\
\hline
\end{tabular}


Bio-oils can be synthesized from sewage sludge by using pyrolysis techniques [3]. Taguchi optimization suggested the best pyrolysis was performed at $450{ }^{\circ} \mathrm{C}, 60 \mathrm{~min}$ and $10^{\circ} \mathrm{C} / \mathrm{min}$, which also showed consistency with other research work. Nonetheless, under most conditions, pyrolytic oil/bio-oil requires further processing or upgrading for use as biodiesel. To maintain the stability of bio-oil, blending with emulsifier resulted in high solubility (58.83-70.96 wt \%) [4]. These findings suggest that simple blending could improve the properties of biodiesel or bio-oil tremendously, which is worthy of further investigation. Aside from using bio-oil as a precursor for biodiesel [3], biodiesel could be directly synthesized using other oil materials such as Australian native stone fruit oil [6], rapeseed oil [7], Rhodotorula glutinis [8] and soursop seed oil [9] via transesterification techniques. Transesterification of Australian native stone biodiesel showed a high yield of $95.8 \%$ with the response surface methodology optimization and its quality fulfilled the ASTM D6751 and EN14214 requirements [6]. Kuan et al. [8] investigate both direct acid and base-transesterification on Rhodotorula glutinis biomass which gave $111 \%$ yield of FAME and $102 \%$ yield of FAME, respectively, which were regarded as of good biodiesel quality. Another research work by Su et al. [9] used soursop seed to produce bio-oil which was eventually upgraded to biodiesel using a two-step acid catalyzed transesterification. The biodiesel produced met both EN14214 and D6751 standards. Encinar et al. [7] performed rapeseed transesterification with $\mathrm{KOH}$ catalyst as well as with the aid of ultrasound whereby the kinetic behavior obeyed a pseudo-first order trend. Liquid lipase-based esterification was attempted and optimized using RSM to enhance the usage of water removal agent in the system [11]. In Anwar et al's, [5] work, it was found that by blending papaya oil biodiesel with varying contents (5-20\%) with diesel could improve the engine testing properties. Microalgal biodiesel was generated using photobioreactor with coal-fired flue gas from three strains (M082, M134 and KR-1) [10]. Among the strains, M082 generated high lipid value of $397 \mathrm{mg} / \mathrm{g}$ which was regarded to be a suitable feedstock for biodiesel production.

In recent years, gasification also garners high interest due to its rapid processing step and high yield of syngas which could be directly used for combustion. One of the main constitutes of syngas is hydrogen which usually provides high calorific value. Based on Chein and Hsu's [12] work, the tri-reforming process could produce good quality syngas. In addition, it was also found that at higher reaction temperatures, more hydrogen and carbon monoxide were produced. In pilot plant study, the gasifier which was embedded with specific solid oxide fuel cell system in an industrial scale was investigated in details [13]. To further understanding the gasification process, a thermodynamic equilibrium constants derivation and modelling was performed for two cases, with and without tar. The simulated data were validated with experimental data [14]. These findings could serve as good guides for future development of gasification process.

Bio-digester or bioreactor could also be used for biogas production. Černý et al. [15] discovered that microorganisms such as Clostridium novyi were detected at higher ratio $(65.63 \%)$ in the population of the bioreactor for the biogas production. Such detection could serve as an important reminder to seek ways to inhibit these harmful microorganisms in the system. In an investigation and survey of 107 biogas plants, it was also found that the younger plant ( $<5$ years) produced higher $\mathrm{CH}_{4}(65.44 \%)$ and $\mathrm{CO}_{2}(29.31 \%)$ [16]. Addition of granular activated carbon (GAC) in the digestion system could also directly improve the methane production by more than $34 \%$ [17]. Thermophilic anaerobic digestion is another interesting field of research. David et al. [18] found that by co-digestion under such conditions, high yield of methane (up to $305.45 \mathrm{~kg} / \mathrm{L}$ ) could be achieved. Musa's work critically reviewed some of the more critical findings on anaerobic membrane reactors for biogas recovery especially on membrane fouling and parameters of operation [19].

The studies on alcohol-based biofuels are increasing due to its high energy-content and suitability as fuel products. Dziekońska-Kubczak et al. [20] report that nitric acid as a form of chemical pretreatment could enhance the bioethanol production up to $30 \%$. A Polymer Electrolyte Membrane Fuel Cell was used to produce isopropanol from acetone for use as a biofuel [21]. The hydrogenation process consumes less energy and less chemical wastes compared to other 
techniques [21]. Bio-hydrocarbons (alcohol and alkenes) produced from bacteria and their synthesis mechanisms are reviewed by Rahman et al. [22], as well as future challenges and complexity.

High pressure densification and torrefaction are currently attracting attention among the research community as these methods can produce potential solid-based fuels which require no further upgrade and can be use directly. Both methods are usually applied in mild synthesis conditions which differ from common thermochemical conversion techniques like slow pyrolysis and fast pyrolysis. For example, biomass with low ash content (1.16-8.62\%) and good mechanical durability $(97 \%)$ such as bamboo fibre and sugarcane skin could be directly densified as bio-briquette fuel without any energy processing [24]. As for torrefaction, a form of mild pyrolysis, wood wastes could be converted into torrefied biomass as low as $300^{\circ} \mathrm{C}$ [23]. As observed, both methods consume relatively lower energy requirement and are simpler in term of synthesis process. In a modelling study, Lycopodium particles were also simulated and modelled as biofuel and burned in air environment [25]. It was discovered that the particles of Lycopodium were greatly influenced by thermophoretic force. Microbial fuel cell studies were also being investigated thoroughly. The effect of the hydrodynamic layer thickness was found to be significant on the voltage and charged transfer resistance [26]. In another study, the calcination temperature on the cathodic chambers was studied and it was found that the electrode synthesized at $500{ }^{\circ} \mathrm{C}$ could degrade oily wastewater up to $99.3 \%$ [27]. Thus, the microbial fuel cell shows tremendous potential to be developed for other applications.

Conflicts of Interest: The authors declare no conflict of interest.

\section{References}

1. Kim, S.; Um, B.; Im, D.; Lee, J.; Oh, K. Combined Ball Milling and Ethanol Organosolv Pretreatment to Improve the Enzymatic Digestibility of Three Types of Herbaceous Biomass. Energies 2018, 11, 2457. [CrossRef]

2. Kim, T.; Im, D.; Oh, K.; Kim, T. Effects of Organosolv Pretreatment Using Temperature-Controlled Bench-Scale Ball Milling on Enzymatic Saccharification of Miscanthus $\times$ giganteus. Energies 2018, 11, 2657. [CrossRef]

3. Chen, G.-B.; Li, J.-W.; Lin, H.-T.; Wu, F.-H.; Chao, Y.-C. A Study of the Production and Combustion Characteristics of Pyrolytic Oil from Sewage Sludge Using the Taguchi Method. Energies 2018, 11, 2260. [CrossRef]

4. $\quad$ Längauer, D.; Lin, Y.-Y.; Chen, W.-H.; Wang, C.-W.; Šafář, M.; Čablík, V. Simultaneous Extraction and Emulsification of Food Waste Liquefaction Bio-Oil. Energies 2018, 11, 3031. [CrossRef]

5. Anwar, M.; Rasul, M.; Ashwath, N. A Systematic Multivariate Analysis of Carica papaya Biodiesel Blends and Their Interactive Effect on Performance. Energies 2018, 11, 2931. [CrossRef]

6. Anwar, M.; Rasul, M.; Ashwath, N.; Rahman, M. Optimisation of Second-Generation Biodiesel Production from Australian Native Stone Fruit Oil Using Response Surface Method. Energies 2018, 11, 2566. [CrossRef]

7. Encinar, J.; Pardal, A.; Sánchez, N.; Nogales, S. Biodiesel by Transesterification of Rapeseed Oil Using Ultrasound: A Kinetic Study of Base-Catalysed Reactions. Energies 2018, 11, 2229. [CrossRef]

8. Kuan, I.-C.; Kao, W.-C.; Chen, C.-L.; Yu, C.-Y. Microbial Biodiesel Production by Direct Transesterification of Rhodotorula glutinis Biomass. Energies 2018, 11, 1036. [CrossRef]

9. Su, C.-H.; Nguyen, H.; Pham, U.; Nguyen, M.; Juan, H.-Y. Biodiesel Production from a Novel Nonedible Feedstock, Soursop (Annona muricata L.) Seed Oil. Energies 2018, 11, 2562. [CrossRef]

10. Kim, B.; Praveenkumar, R.; Choi, E.; Lee, K.; Jeon, S.; Oh, Y.-K. Prospecting for Oleaginous and Robust Chlorella spp. for Coal-Fired Flue-Gas-Mediated Biodiesel Production. Energies 2018, 11, 2026. [CrossRef]

11. Nguyen, H.; Huong, D.; Juan, H.-Y.; Su, C.-H.; Chien, C.-C. Liquid Lipase-Catalyzed Esterification of Oleic Acid with Methanol for Biodiesel Production in the Presence of Superabsorbent Polymer: Optimization by Using Response Surface Methodology. Energies 2018, 11, 1085. [CrossRef]

12. Chein, R.-Y.; Hsu, W.-H. Analysis of Syngas Production from Biogas via the Tri-Reforming Process. Energies 2018, 11, 1075. [CrossRef]

13. Fernandes, A.; Brabandt, J.; Posdziech, O.; Saadabadi, A.; Recalde, M.; Fan, L.; Promes, E.; Liu, M.; Woudstra, T.; Aravind, P. Design, Construction, and Testing of a Gasifier-Specific Solid Oxide Fuel Cell System. Energies 2018, 11, 1985. [CrossRef] 
14. Eri, Q.; Wu, W.; Zhao, X. Numerical Investigation of the Air-Steam Biomass Gasification Process Based on Thermodynamic Equilibrium Model. Energies 2017, 10, 2163. [CrossRef]

15. Černý, M.; Vítězová, M.; Vítěz, T.; Bartoš, M.; Kushkevych, I. Variation in the Distribution of Hydrogen Producers from the Clostridiales Order in Biogas Reactors Depending on Different Input Substrates. Energies 2018, 11, 3270. [CrossRef]

16. Roubík, H.; Mazancová, J.; Le Dinh, P.; Dinh Van, D.; Banout, J. Biogas Quality across Small-Scale Biogas Plants: A Case of Central Vietnam. Energies 2018, 11, 1794. [CrossRef]

17. Valero, D.; Rico, C.; Canto-Canché, B.; Domínguez-Maldonado, J.; Tapia-Tussell, R.; Cortes-Velazquez, A.; Alzate-Gaviria, L. Enhancing Biochemical Methane Potential and Enrichment of Specific Electroactive Communities from Nixtamalization Wastewater using Granular Activated Carbon as a Conductive Material. Energies 2018, 11, 2101. [CrossRef]

18. David, A.; Govil, T.; Tripathi, A.; McGeary, J.; Farrar, K.; Sani, R. Thermophilic Anaerobic Digestion: Enhanced and Sustainable Methane Production from Co-Digestion of Food and Lignocellulosic Wastes. Energies 2018, 11, 2058. [CrossRef]

19. Musa, M.; Idrus, S.; Che Man, H.; Nik Daud, N. Wastewater Treatment and Biogas Recovery Using Anaerobic Membrane Bioreactors (AnMBRs): Strategies and Achievements. Energies 2018, 11, 1675. [CrossRef]

20. Dziekońska-Kubczak, U.; Berłowska, J.; Dziugan, P.; Patelski, P.; Pielech-Przybylska, K.; Balcerek, M. Nitric Acid Pretreatment of Jerusalem Artichoke Stalks for Enzymatic Saccharification and Bioethanol Production. Energies 2018, 11, 2153. [CrossRef]

21. Li, C.; Sallee, A.; Zhang, X.; Kumar, S. Electrochemical Hydrogenation of Acetone to Produce Isopropanol Using a Polymer Electrolyte Membrane Reactor. Energies 2018, 11, 2691. [CrossRef]

22. Rahman, Z.; Nawab, J.; Sung, B.; Kim, S. A Critical Analysis of Bio-Hydrocarbon Production in Bacteria: Current Challenges and Future Directions. Energies 2018, 11, 2663. [CrossRef]

23. Poudel, J.; Karki, S.; Oh, S. Valorization of Waste Wood as a Solid Fuel by Torrefaction. Energies 2018, 11, 1641. [CrossRef]

24. Brunerová, A.; Roubík, H.; Brožek, M. Bamboo Fiber and Sugarcane Skin as a Bio-Briquette Fuel. Energies 2018, 11, 2186. [CrossRef]

25. Bidabadi, M.; Ghashghaei Nejad, P.; Rasam, H.; Sadeghi, S.; Shabani, B. Mathematical Modeling of Non-Premixed Laminar Flow Flames Fed with Biofuel in Counter-Flow Arrangement Considering Porosity and Thermophoresis Effects: An Asymptotic Approach. Energies 2018, 11, 2945. [CrossRef]

26. Chen, Y.-M.; Wang, C.-T.; Yang, Y.-C. Effect of Wall Boundary Layer Thickness on Power Performance of a Recirculation Microbial Fuel Cell. Energies 2018, 11, 1003. [CrossRef]

27. Wu, J.-C.; Yan, W.-M.; Wang, C.-T.; Wang, C.-H.; Pai, Y.-H.; Wang, K.-C.; Chen, Y.-M.; Lan, T.-H.; Thangavel, S. Treatment of Oily Wastewater by the Optimization of Fe2O3 Calcination Temperatures in Innovative Bio-Electron-Fenton Microbial Fuel Cells. Energies 2018, 11, 565. [CrossRef] 